\title{
SCRM Analysis of PT. SupermarketBangunan with a Balanced Scorecard Approach
}

\author{
D H Yohandy ${ }^{* 1}$, G G Hungilo ${ }^{2}$ \\ ${ }^{1}$ Master of Informatics, Universitas Atma Jaya Yogyakarta \\ ${ }^{2}$ Ministry of Home Affairs, Tanzania
}

E-mail: nverbe94@gmail.com¹, gilberthungilo@gmail.com²

Submitted: 5 February 2021, revised: 17 February 2021, accepted: 18 February 2021

\begin{abstract}
Abstrak. Penggunaan media sosial semakin bervariasi dan penuh inovasi seiring dengan perkembangan teknologi informasi. Awalnya media sosial dimaksudkan sebagai sarana berkomunikasi di dunia digital dan bersosialisasi dengan orang lain tanpa dibatasi jarak dan waktu, namun kini sudah mulai memiliki nilai di dunia bisnis. Contoh paling awal yang diketahui dan sudah digunakan adalah penggunaan media sosial untuk promosi, iklan, dan informasi tentang layanan baru. Namun, ketika perusahaan menyadari nilai hubungan sosial dengan pelanggan, media sosial kembali berperan dalam menjaga hubungan dengan pelanggan mereka. Untuk keperluan bisnis, risiko merupakan masalah yang harus diminimalisir bahkan dihindari. Penerapan media sosial dalam dunia bisnis masih berisiko dan diperlukan penilaian standar untuk menilai apakah return value yang akan diperoleh itu setimpal atau tidak. Oleh karena itu, penelitian ini menggunakan studi kasus PT bahan bangunan dalam mengimplementasikan Social Customer Relationship Management dalam proses bisnis dan menilai dengan menggunakan standar Balanced Scorecard.
\end{abstract}

Kata Kunci: Media Sosial; Pelanggan; Manajemen Hubungan Pelanggan Sosial; Balanced Scorecard.

\begin{abstract}
The use of social media is increasingly varied and full of innovation along with the development of information technology. Initially it was intended as a means of communicating in the digital world and socializing with other people without being limited by distance and time, but now it is starting to have values in the business world. The earliest known and used examples are the usage of social media for promotions, advertisements, and info about new services. Since companies become aware of the value of social relationships with customers, social media is again taking part for companies to maintain relationships with their customers. For business purposes, risk is a problem that must be minimized and even avoided. The application of social media in business is still risky so a standard assessment is needed to measure whether the return value that will be obtained is worth it or not. Therefore, this research uses a case study of a PT SupermarketBangunan in implementing Social Customer Relationship Management (SCRM) in business processes and assesses the SCRM using the standards of the Balanced Scorecard.
\end{abstract}

Keywords: Social media; Customers; Social Customer Relationship Management; Balanced Scorecard. 


\section{Introduction}

Technological developments in this era of globalization affect almost all aspects of business life, starting from the monetary values. All companies want IT (information technology) to help their businesses reap as much profit as possible because the costs required to build the infrastructure are high. Now IT is not exclusive to the elite that almost all companies apply to use of IT in their respective fields. The application can be either in the form of software or systems such as servers regarding that the costs are getting more affordable. Although competition and innovation are more challenging, there are always new ways and opportunities to win the competition with other companies. Therefore, many companies have begun to switch to optimizing the value of customer relationships for example CRM (Customer Relationship Management). CRM can be used to store customer data and use it for specific purposes such as promotions and advertisements regarding the products and services that match the customers' interests. CRM plays a role as the main bridge in building relationships between customers and the management team, and a good CRM contributes to companies in retaining customers and gaining profits in the market through word of mouth advertising [1].

However, CRM does not reach its peak in IT implementation in customer relationships since the implementation of social media is seen to be more suitable to be considered to get values from the customer relationships. To study this, SCRM (Social Customer Relationship Management) is applied, which focuses on the role of social media to support CRM. Social customer relationship management (SCRM) can provide insight into the company, which will help encourage companies to make customercentered innovations [2]. Many companies have started to implement SCRM in their business processes, but the results obtained are not optimal and are not worth the investment spent to implement SCRM in their companies.

To deal with this problem, an assessment standard such as a framework is needed to evaluate the performance of SCRM in a company. The assessment is used to minimize risks and ensure that the steps taken in the SCRM process are correct. However, the standards created cannot be one-for-all, because the characteristics and business processes of each company are different. Companies engaged in the health sector and companies in the insurance sector certainly have different methods of implementing SCRM and the value expected by implementation. Therefore, the assessment standard must be efficient and adaptable to the characteristics of each company. There are several methods for measuring CRM performance, such as the balanced scorecard and CRM scorecard. Despite the similarity of the two methods, CRM Scorecard focuses more on the measurement system that specifically deals with CRM strategy and customer profitability objectives [3].

This study applies a balanced scorecard approach to assess the performance of SCRM in companies that are the case studies in this research. The balanced scorecard is a measuring tool that helps provide top managers with a comprehensive view of four perspectives: finance, customers, internal business processes, and innovation and learning. Although the BSC is a fairly powerful measuring tool, it needs to be adjusted in order to measure CRM effectively [4].

\section{Theories \& Related Works}

\subsection{Social media}

The adoption of social media and its use in the private domain continue to expand and grow rapidly. Many companies use Facebook and Twitter as the main means of using social media for their business. Moreover, now social media users hope that well-known companies and brands have social media platforms [5].

Social media is defined as a group of internet-based applications that are built on the ideology and technological foundations of Web 2.0 that allow the creation and exchange of user-generated content. There are many social media that can be found in everyday life, for example Facebook, Twitter, LinkedIn, and Path. There are also social media with more specific purposes such as Youtube, Flickr, 
Wikipedia, and many others. In the business world, the types of social media that are usually used are blogs, microblogs, social networking sites, and social sharing websites [6].

The positive impacts and benefits that companies can get by using social media can vary such as:

a) Build long-term relationships with customers

b) The company can create a group or community where there is not only a relationship between the company and the customer, but also the relationship between one customer to the other customer.

c) With good relationships, customers will tend to give feedback, input, and suggestions that are critical so that the company has a chance to be better.

d) Creating content such as advertisements or promotions on social media will tend to be seen and noticed and responded by customers more often because they focus on their social media platforms.

The business processes that have great potential to be influenced and affected positively by are marketing, sales, and customer services. The reasons are that these 3 aspects are directly related to customers and the success value of each aspect is influenced by the number of customers who get benefits and feel satisfied with the service in these aspects.

Figure 1 shows an example of the use of social media in marketing, sales and customer services [1].

\begin{tabular}{|c|c|c|c|}
\hline $\begin{array}{c}\text { Social } \\
\text { channel }\end{array}$ & Marketing & Sales & Customer Service \\
\hline Blog & $\begin{array}{l}\text { - blog focused on buil- } \\
\text { ding reputation, written } \\
\text { by a senior executive. } \\
\text { - focus on leadership }\end{array}$ & $\begin{array}{l}\text { - deals with members of a } \\
\text { community, for the acquisi- } \\
\text { tion of products and servi- } \\
\text { ces. }\end{array}$ & $\begin{array}{l}\text { - capture of comments in the } \\
\text { executive blog regarding } \\
\text { claims or requests by cu- } \\
\text { stomers, and to act accor- } \\
\text { dingly. }\end{array}$ \\
\hline $\begin{array}{l}\text { Internal } \\
\text { Wiki }\end{array}$ & $\begin{array}{l}\text { - platform to share mar- } \\
\text { ket knowledge that has } \\
\text { been collected from } \\
\text { conversations with cu- } \\
\text { stomers. }\end{array}$ & $\begin{array}{l}\text { - shared presentations on } \\
\text { sales and common } \\
\text { knowledge about new sales } \\
\text { leads. }\end{array}$ & $\begin{array}{l}\text { - creation of a knowledge } \\
\text { base of customer service } \\
\text { procedures. }\end{array}$ \\
\hline $\begin{array}{l}\text { Video shar- } \\
\text { ing web- } \\
\text { sites (e.g., } \\
\text { YouTube) }\end{array}$ & $\begin{array}{l}\text { - viral advertising propa- } \\
\text { gated only online, enco- } \\
\text { uraging word-of-mouth } \\
\text { reference. }\end{array}$ & $\begin{array}{l}\text { - point of contact to create } \\
\text { sales opportunity in another } \\
\text { channel. }\end{array}$ & $\begin{array}{l}\text { - publication of educational } \\
\text { videos on how to use certa- } \\
\text { in product, extending the } \\
\text { user manual online. }\end{array}$ \\
\hline $\begin{array}{l}\text { Micro } \\
\text { Blogging } \\
\text { (e.g., Twit- } \\
\text { ter) }\end{array}$ & $\begin{array}{l}\text { - messages to announce } \\
\text { special offers and di- } \\
\text { scounts. } \\
\text { - spreading of viral mar- } \\
\text { keting campaigns, inte- } \\
\text { gration with channels } \\
\text { like YouTube. }\end{array}$ & $\begin{array}{l}\text { - launching of exclusive pro- } \\
\text { duct offers for Twitter fol- } \\
\text { lowers, as a way of looking } \\
\text { for new sales opportunities. } \\
\text { - focus on the current follo- } \\
\text { wer base. }\end{array}$ & $\begin{array}{l}\text { - } \text { response to support inqui- } \\
\text { ries and product compla- } \\
\text { ints, monitored by an ex- } \\
\text { clusive team. } \\
\text { - focus on all digital custo- } \\
\text { mers. }\end{array}$ \\
\hline $\begin{array}{l}\text { Social } \\
\text { Network- } \\
\text { ing Sites } \\
\text { (e.g., Face- } \\
\text { book) }\end{array}$ & $\begin{array}{l}\text { - spreading of advertising } \\
\text { campaigns within the } \\
\text { communities of clients. }\end{array}$ & $\begin{array}{l}\text { - launch of new product and } \\
\text { benefit campaigns for } \\
\text { community members only. } \\
\text { - focus on the current follo- } \\
\text { wer base. }\end{array}$ & 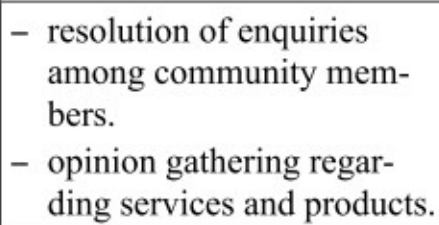 \\
\hline
\end{tabular}

Source: Deloitte, CRM 2.0 or Social CRM for Financial Industry, http://www.deloitte.com/assets/DcomCroatia/Local\%20Assets/Documents/2012/FSINews03.02-Social_CRM.pdf; D. Buchnowska, Social business - a conceptual framework, [in:] Business Informatics, no 4 (30), Wydawnictwo Uniwersytetu Ekonomicznego we Wrocławiu, Wrocław 2013; J. Palonka, T. Porębska-Miąc, From Social media to Social CRM (SCRM), [in:] Creativity support systems, methods and applications, SE 117, Wydawnictwo Uniwersytetu Ekonomicznego w Katowicach, Katowice 2012.

Figure 1. The role of social media in business processes 


\subsection{Customer relationship management}

Customer Relationship Management (CRM) is a customer-oriented business philosophy [7]. CRM includes analysing, planning, and monitoring customer relationships using the latest information and communication technologies. Until now, many companies have implemented CRM in their companies with a mission to get new customers and retain repeat customers. The implementation of CRM in companies must be in accordance with their business processes and cannot just implement a system to deal with customers. Marketing in a company must know how to attract and continue to attract customers, CRM is only a means to simplify that mission.

\subsection{Social customer relationship management}

Social media is the center where most people leave comments and opinions on the products and services they have tried. They usually aim to provide input to others whether some products or services are good or bad. Comments and input from customers are valuable data that can be used by companies related to, or engaged in, the same field with the products mentioned. Most companies are interested and take part in utilizing this data to be values for them. Therefore, SCRM is increasingly in demand and open for further research. Social CRM changes the relationship between customers and providers from just a transactional pattern to a pattern of involving customers as partners in innovation [8].

This new technique emphasizes communication and dialogue between stakeholders to get customer satisfaction, and good feedback for service providers [9]. When someone is familiar with a product, that person has a portion of the time dedicated to that product. The relationship between the two tends to increase, especially in online media, whether on customers' social media or on product brands' [10]. However, to implement SCRM, the company needs a high enough analytical technique to convert the available "Big Data" into a responsive input. Enterprise systems also require fairly advanced modeling and data processing methods.

In business, there are several related SCRM use cases, namely [5]:

a. SCRM Marketing

In this use case, SCRM focuses on managing knowledge and ideas aimed at getting new ideas in developing products and services. There are 2 examples of processes, namely social campaigns that focus on maintaining relationships with a community of users, and public relations that aim to maintain the company's reputation and control all kinds of communications that affect the company.

\section{b. SCRM for Sales}

As the most customer-facing department, sales are the area that has the greatest potential and opportunity to become a focus area for a company's SCRM.

c. SCRM for Customer Services

SCRM use cases in this scope aim to maintain relationships with the customers who can give the biggest potential innovations. There are 2 types of examples of the use of SCRM in this scope namely community peer-to-peer support, which focuses on the community to help each other, and listen-andrespond service, that uses media to detect and respond the needs of customers regarding the company's products and services.

In Figure 2, the table shows the use of SCRM in 3 business aspects, namely marketing, sales and customer services [1]. 


\begin{tabular}{|c|c|c|}
\hline & Use cases & Type of applications (example) \\
\hline $\begin{array}{l}\text { Social } \\
\text { CRM for } \\
\text { Marketing }\end{array}$ & $\begin{array}{l}\text { - Idea management } \\
\text { - New product or service proposition } \\
\text { and market research } \\
\text { - New product or service launch to } \\
\text { market } \\
\text { - Social campaigns } \\
\text { - Social event networking } \\
\text { - Public Relations, brand/reputation } \\
\text { promotion and defense }\end{array}$ & $\begin{array}{l}\text { - Social media monitoring (Nielsen BuzzMetrics, } \\
\text { TNS Cymfony) } \\
\text { - Hosted community platforms (e.g. Communi- } \\
\text { space, LiveWorld) }\end{array}$ \\
\hline $\begin{array}{l}\text { Social } \\
\text { CRM for } \\
\text { Sales }\end{array}$ & $\begin{array}{l}\text { - Social sales prospecting and research } \\
\text { - Sales social collaboration }\end{array}$ & $\begin{array}{l}\text { - Social contact management with data derived } \\
\text { from communities (InsideView, salesforce.com } \\
\text { Jigsaw and ZoomInfo) } \\
\text { - Lead Management (CDC Pivotal Social CRM, } \\
\text { IsideView, salesforce.com Jigsaw) } \\
\text { - Call planning (Artesian Solution and Oracle } \\
\text { Social Prospector) } \\
\text { - Sales content management with social software } \\
\text { providing a collaborative environment (iCente- } \\
\text { ra, Oracle Social CRM Sales Library, salesfor- } \\
\text { ce.com Chatter) } \\
\text { - Social media monitoring (Radian6,Visible } \\
\text { Technologies) } \\
\text { - Proposal management with social software pro- } \\
\text { viding a collaborative environment (Brightidea } \\
\text { Switchboard) } \\
\text { - Social network analysis (7 Degrees, Saba and } \\
\text { Trampoline Systems) }\end{array}$ \\
\hline $\begin{array}{l}\text { Social } \\
\text { CRM for } \\
\text { Customer } \\
\text { Service }\end{array}$ & $\begin{array}{l}\text { - Community peer-to-peer support } \\
\text { - Service customer feedback } \\
\text { - Service listen and respond } \\
\text { - Service process analysis }\end{array}$ & $\begin{array}{l}\text { - Enterprise feedback management (Globalpark, } \\
\text { MarketTools) } \\
\text { - Hosted communities with search, integration } \\
\text { tools, workflow and rule engines (Jive, Live- } \\
\text { World, RightNow) } \\
\text { - Social media monitoring (Cisco SocialMiner, } \\
\text { Radian6, RightNow) } \\
\text { - Text mining (Attensity, Clarabridge) }\end{array}$ \\
\hline
\end{tabular}

Source: based on: Gartner, Top Use Cases and Benefits for Successful Social CRM, http://img2.insight.com/graphics/fr/adobe/insight_articlel3.pdf.

Figure 2. The role of the SCRM use case

\subsection{Balanced scorecard}

This concept was developed by Robert Kaplan and David Norton which aims to change a company's strategy into objectives and to measure company performance, goals, and initiatives [11]. The Balanced Scorecard is based on 4 balanced perspectives and combines these perspectives with the concept of cause and effect. These perspectives include 1. Finance, 2. Customers, 3. Internal Processes, 4. Employee learning and growth.

Figure 3 shows the Balanced Scorecard methodology [12]. 


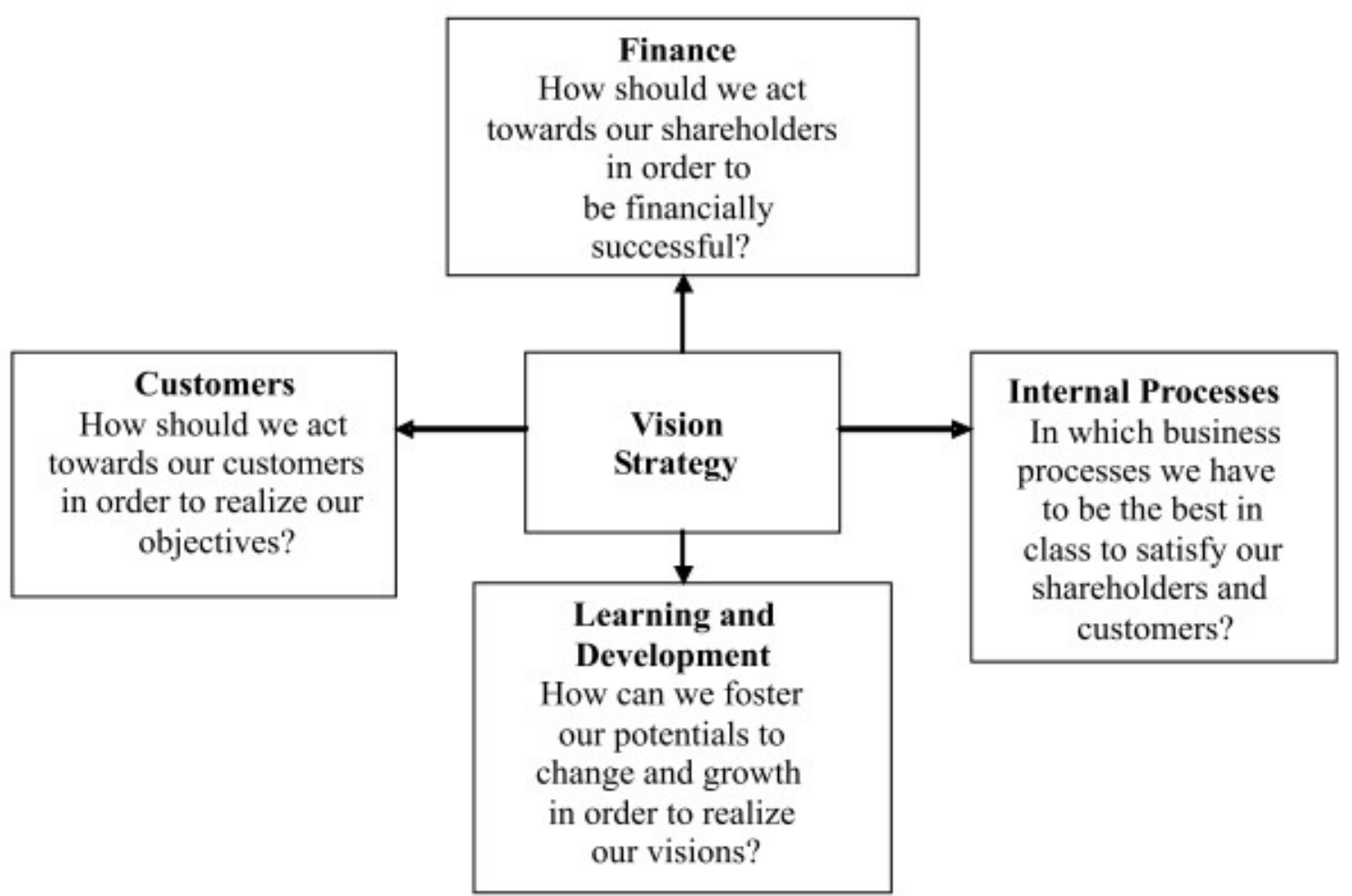

Figure 3. Balanced Scorecard Methodology

Kaplan and Norton's Balanced Scorecard focuses not only on the financial side but also on the customers and their respect for the company [13]. Based on that, here are the key indicators:

a) Clients, the essential foundation for any business.

b) Good results come first

c) Innovation and learning

d) Financial point of view

e) Studying feedback

Research on financial markets in Lebanon shows that the markets are influenced by governance, Islamic financial principles, and the existence of barriers to outside participation. This causes the Lebanese financial sector to be low even though its regulations, supervisors and accounting standards meet international standards. The author aims to examine these case studies then provide reasons and recommendations regarding the failure of CRM in optimally implementing information management [7].

From social media, it can be obtained the users' experience and knowledge regarding the products and services they comment on. This is seen as a "Big Data" that can be utilized by the company. However, to turn this data into the company's business value, it needs the right approach and the appropriate standards. Therefore, the author uses the SCRM concept in his research with the aim of creating a framework which can retrieve and sort important data for the company from all reviews and comments on social media. The case study taken is Twitter social media and uses a framework based on Hadoop MapReduce and HBase [14].

The author uses a literature study method to systematically see the factors that influence each other in determining the most effective method to achieve company goals. Researchers use the balanced scorecard as a means of communication for a company from top management to lower level management so that all elements of the company know their role in achieving company goals [15]. 
The author sees that information technology (IT), which was once expensive and scarce, is a vital key to running a business today. This large development requires flexible management techniques so that businesses can manage their IT performance. The Balanced Scorecard is a widely used approach to measure IT management performance. The author aims to examine and evaluate the BSC in IT and the adaptability of the BSC to the latest IT developments. The expected results are two new scorecards, namely IT BSC for services and service portfolios [16].

This study aims to create a framework based on balanced scorecard for evaluating the performance of SCRM in a company. Based on the SCRM use case in the scope of marketing, sales and customer services, the scorecard framework is made to find out the value and return value obtained from investing in the company's SCRM. The assessment is taken based on the company's account activity on social media, the expert staff or owner of the social media account [5].

\section{Research Methodology}

This research uses the interview method on a case study from PT. SupermarketBangunan which is quite large and active in its social media. Initially, PT. SupermarketBangunan only used social media to advertise new products and promotions. However, this activity was considered to be not maximum and there was still a lot of space and potential that could be utilized for the business value of PT. SupermarketBangunan's company, which stated that they were engaged in business with the category of building supermarkets.

The questions submitted to the resource person (IT staff at PT. SupermarketBangunan) were adopted from a study [5] which included the following factors:

a) Company Background

b) Social CRM Goals \& Objectives

c) Social CRM Performance Measurement \& Metrics

d) Respondent Data

Table 1 contains a list of questions asked:

Table 1. List of questions asked

\begin{tabular}{|c|c|c|c|}
\hline Company Background & $\begin{array}{c}\text { Social CRM Goal } \\
\text { \& Objective }\end{array}$ & $\begin{array}{c}\text { Social CRM } \\
\text { Performance } \\
\text { Measurement \& } \\
\text { Metrics }\end{array}$ & Respondent Data \\
\hline $\begin{array}{l}\text { Since when has social } \\
\text { media been used in } \\
\text { companies? }\end{array}$ & $\begin{array}{l}\text { History and vision for } \\
\text { the future in using } \\
\text { social media? }\end{array}$ & $\begin{array}{l}\text { How is the assessment } \\
\text { of the role of SCRM } \\
\text { that has been } \\
\text { implemented? }\end{array}$ & $\begin{array}{l}\text { What are the duties and } \\
\text { responsibilities as } \\
\text { owner and who play a } \\
\text { role in the company's } \\
\text { SCRM activities? }\end{array}$ \\
\hline $\begin{array}{l}\text { Reasons for using } \\
\text { social media? }\end{array}$ & $\begin{array}{l}\text { What SCRM use cases } \\
\text { are the most dominant } \\
\text { in use? }\end{array}$ & $\begin{array}{l}\text { How to control and } \\
\text { monitor SCRM } \\
\text { implementation? }\end{array}$ & $\begin{array}{l}\text { Good and bad } \\
\text { experiences in playing a } \\
\text { role in the company's } \\
\text { SCRM? }\end{array}$ \\
\hline $\begin{array}{l}\text { How big is the adoption } \\
\text { of social media in the } \\
\text { company? }\end{array}$ & $\begin{array}{l}\text { How can this use case } \\
\text { help you achieve your } \\
\text { company's vision and } \\
\text { mission? }\end{array}$ & $\begin{array}{l}\text { Is there a standard } \\
\text { assessment for the } \\
\text { SCRM method? }\end{array}$ & \\
\hline $\begin{array}{l}\text { How big is the } \\
\text { company's innovation } \\
\text { level? }\end{array}$ & & $\begin{array}{l}\text { Important factors in } \\
\text { implementing SCRM in } \\
\text { a company? } \\
\text { How to assess the } \\
\text { return value of an } \\
\text { intangible SCRM } \\
\text { investment? }\end{array}$ & \\
\hline
\end{tabular}




\section{Results and Discussion}

\subsection{A glimpse of PT. SupermarketBangunan's approach to social media}

To get useful knowledge and direction, the social media IT staff at this company adapts the methods used by the competitors like IKEA as a guide and reference. Because IKEA is a very large company with communities in several countries, there is no doubt that its activities including online sales would be effective. To get greater significance, the company uses other platforms like InstaAds, FbAds, Instagram, Facebook, and Twitter with an average number of accounts of 5 per platform.

\subsection{Results of the interview session}

Then based on the questions that have been asked (based on Table 1) the following are the results obtained regarding SCRM at PT. SupermarketBangunan :

a. Company Background

Starting from the SCRM use case, this company has implemented a use case for Marketing from the beginning of social media implementation, followed by Customer Service and SCRM Sales. Although customers still visit the physical, the application in the marketing sector has gradually become the main means for promotion, advertising and event info. This is done to engage loyal customers and also to attract new customers. To maximize the result, the company tries to increase sales (use case sales) and maintains the customer complaint service (use case customer service). The company's expectation with the application of SCRM in their business processes is to be the trendsetter in building supermarkets. Social media is also used to monitor competitors' actions, to learn and find out what steps must be taken to stay competitive, and to keep suppliers providing goods smoothly.

\section{b. Objectives}

From the interview, social media was the center and the storehouse of information, for example, Instagram which continues to innovate from a platform for uploading photos to platform for advertising and announcements. What is learned from social media is also the characteristics of each social media, both it's the advantages and disadvantages of using the social media platform. To overcome the shortcomings, the resource person and his team studied competitors to find solutions and learned good patterns in overcoming these problems in order to give the best service to their customers. For future objectives, PT. SupermarketBangunan is using Facebook to collect customer data to keep managing customers at PT. SupermarketBangunan, and until now the results of implementing customer service use cases are arguably effective.

The objective of implementing SCRM compared to the main business objective, namely sales, is arguably directly proportional. Because if the application of SCRM is successful and good, the result will increase. In other words, many customers who come or shop indirectly will increase the sales. Providing good service at offline stores will give good impression to the customers who might spread the information about the reputation of this company. With good reputation new customers are willing to check and even immediately give comments and questions to PT. SupermarketBangunan from the website or social media to get a little picture of PT. SupermarketBangunan.

c. Performance

To support the company's main business, namely sales, the application of SCRM greatly helps sales in offline stores as a means of advertisements, and promos, or events information to reach both customers and potential customers who are far from store locations. For this reason, the resource person tries to build customer's awareness by making people search the company name and event on the internet/social media. Not only building the people awareness of this company, PT. SupermarketBangunan also sees an opportunity to use IT more in improving company performance, such as planning to open online stores considering the significant growing number of consumers who are more comfortable shopping online than visiting offline stores. The obstacles encountered are usually the feedback and the responses obtained do not match expectations. The cause is the lack of attractiveness in the content uploaded to social media. Interesting contents are an important factor in social media so that the social media users are willing to select/see the details of the posts more thoroughly. 
From the non-financial feedback of SCRM, what has been felt is the increasing number of customers coming. Then, many have started to contact customer service and provide feedback and comments to improve the performance of PT. SupermarketBangunan. This can help the company to set the service standard considering that customers must have experience interacting with other companies' SCRM systems via social media. They will evaluate the company's weakness and strengths based on what they have experienced. The results of these thoughts are useful for the company to have clearer ideas of customers' expectation and to focus more in developing the application. It is expected that SCRM supports the business processes better and satisfy customers.

\section{d. Respondent Experience}

According to the respondents and the company's social media team, they continue to learn from experienced people and imitate them. The results show that they developed better. Openness is the most important thing when communicating with customers because customers who give feedback feel that they know better. Any feedback and comments must be accepted and processed whether they can be positive values for the company and become ideas for development.

The IT team created a software that records all customer data and a software that helps the process of reporting indirect purchases, for example through social media. The marketing unit will provide products and other information needed by the buyer. The marketing unit is in charge of negotiating with the buyer and making the buyer satisfied with product info before buying. When the buyer makes a deal, the marketing will record the details of the sales transaction to the software system: the social media platform used, the transaction value, and the products included in the transaction. In this way, the performance of of the social media use in terms of tangible values can be obtained to become a turnover report for management and become data to study changes in customers' social media usage.

\section{Conclusion}

Based on the data obtained from the research, the results are shown in Figure 1 which shows the important factors as a guide to the performance of SCRM in PT. SupermarketBangunan and the order of these factors.

\section{Rating of SCRM Performance Assessment Factors}

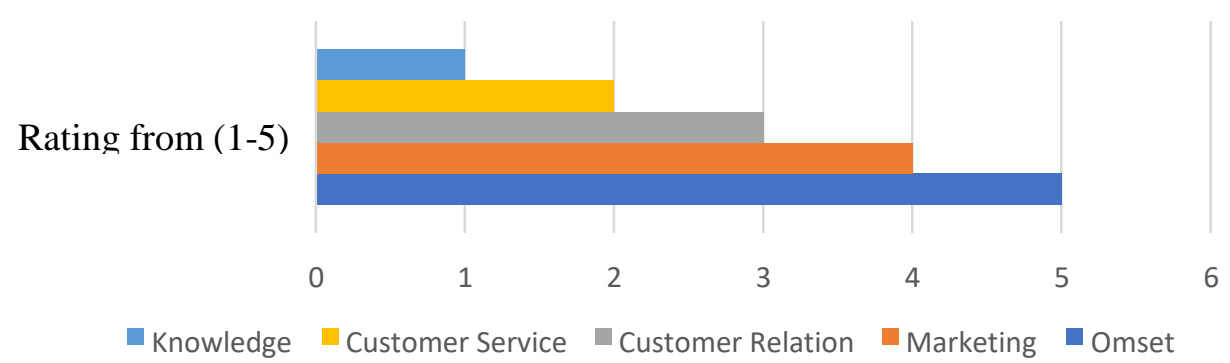

Figure 4. Rating of SCRM Performance Assessment Factors

For the future, PT. SupermarketBangunan maintains relationships with customers as an intermediate objective in addition to prioritizing turnover and marketing for sales as the main objectives. Because PT. SupermarketBangunan uses IT as a sales tool, the company remains focused on sales results that are enhanced by the application of IT and SCRM. Besides that, there is still a gradual plan to create an online shop so that it can compete with other companies that are also engaged in the building supermarket category. It is undeniable that consumers now prefer to shop online and just wait for the product to be delivered to the place. SCRM performance at PT. SupermarketBangunan is still in the 
early stages of learning and seeking knowledge from other companies as a reference for dealing with the obstacles encountered.

In accordance with the Balanced Scorecard methodology proposed by Kaplan and Norton in Figure 3 , the SCRM performance values (from 1-5 with $1=$ Very Bad and $5=$ Very Good) at PT. SupermarketBangunan is shown in Figure 5.

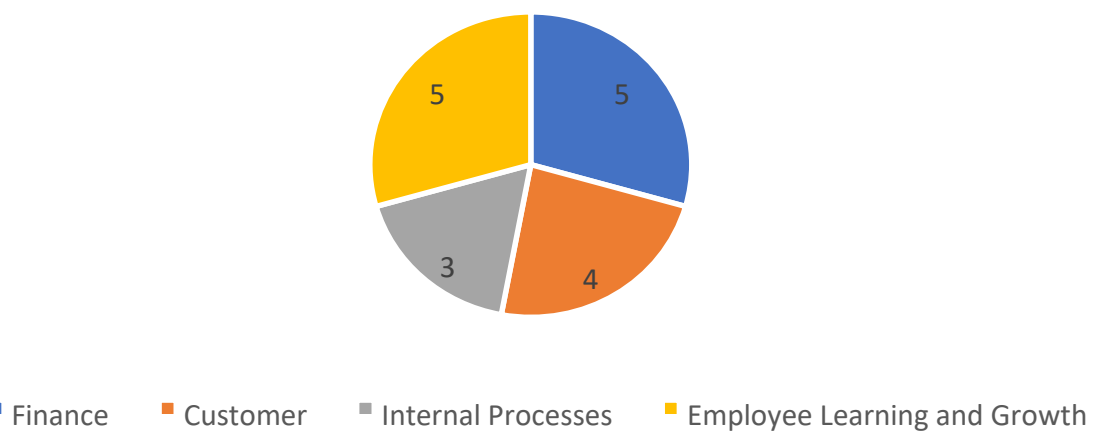

Figure 5. Value of application of the BSC Methodology

\section{References}

[1] M. Hassani, E. Aghaalikhani, M. Hassanabadi, and M. Shakouri Rad, "A study on effects of knowledge management on the success of customer relationship management," Manag. Sci. Lett., 2013, doi: 10.5267/j.ms1.2013.08.022.

[2] M. Nadeem, "Social Customer Relationship Management (SCRM): How Connecting Social Analytics to Business Analytics Enhances Customer Care and Loyalty?," Int. J. Bus. Soc. Sci., vol. 3, no. 21, 2012.

[3] H. SYAFITRI and A. IBRAHIM, "Performance Measuring Analysis of Customer Relationship Management MyXL Using CRM-Scorecard," vol. 172, no. Siconian 2019, pp. 155-166, 2020, doi: 10.2991/aisr.k.200424.023.

[4] A. Ibrahim, A. Pratiwi, D. I. Meytri, Madri, M. A. Kurniawan, and N. Yuniarti, "Measuring Customer Satisfaction Using CRM Scorecard in Canteen FASILKOM UNSRI," Proc. 2018 Int. Conf. Electr. Eng. Comput. Sci. ICECOS 2018, vol. 17, pp. 403-408, 2019, doi: 10.1109/ICECOS.2018.8605253.

[5] F. Kornek, "A Balanced Scorecard Approach To Social CRM Performance Measurement," vol. 3548872, no. 3548872, pp. 1-150, 2012.

[6] M. Hassani, "Management Science Letters," Manag. Sci. Lett., vol. 2, no. 1, pp. 65-80, 2012, doi: $10.5267 /$ j.msl.2012.05.006.

[7] C. Salloum and J. Ajaka, "CRM Failure to Apply Optimal Management Information Systems: Case of Lebanese Financial Sector," Arab Econ. Bus. J., 2013, doi: 10.1016/j.aebj.2013.11.002.

[8] M. Sigala, "Implementing social customer relationship management: A process framework and implications in tourism and hospitality," Int. J. Contemp. Hosp. Manag., vol. 30, no. 7, pp. 2698-2726, 2018, doi: 10.1108/IJCHM-10-2015-0536.

[9] C. H. Baird and G. Parasnis, "From social media to social customer relationship 
management," Strateg. Leadersh., vol. 39, no. 5, pp. 30-37, 2011, doi: 10.1108/10878571111161507.

[10] S. Dewnarain, H. Ramkissoon, and F. Mavondo, "Social customer relationship management: An integrated conceptual framework," J. Hosp. Mark. Manag., vol. 28, no. 2, pp. 172-188, 2019, doi: 10.1080/19368623.2018.1516588.

[11] F. Akbarzadeh, "The Balanced Scorecard ( BSC ) Method : From Theory to Practice," Oman Chapter Arab. J. Bus. Manag. Rev., 2012, doi: 10.12816/0002273.

[12] M. IŠORAITÉ, "the Balanced Scorecard Method: From Theory To Practice," Intelekt. Ekon. Intellect. Econ., 2008.

[13] C. A. Montoya, "The Balanced Scorecard as an Assesment Tool for Administrative Management.pdf," "Visión Futur., vol. 15, no. 2, 2011.

[14] A. El Fazziki, F. Z. Ennaji, A. Sadiq, D. Benslimane, and M. Sadgal, "A multi-agent based social crm framework for extracting and analysing opinions," J. Eng. Sci. Technol., 2017.

[15] W. Endrianto, "Maximizing Strategy with an Effective Balanced Scorecard," The Winners, 2016, doi: 10.21512/tw.v17i1.1805.

[16] A. Györy, W. Brenner, and F. Uebernickel, "Finding the right Balanced Scorecard for business-driven IT management a literature review," 2012, doi: 10.1109/HICSS.2012.280. 